\title{
Cinema and authenticity: anxieties in the making of Historical Film
}

Dominic Lees ${ }^{1}$

Department of Film, Media and Performing Arts, University for the Creative Arts, Farnham, UK

\begin{abstract}
:
The practice of representing history on film brings the filmmaker into collision with a cluster of concerns around the authentic. While recent articles have considered the historical documentary and historical dramatization, I seek to extend the debate into narrative fiction film set in historical periods. In this article, I discuss conflicting conceptions of authenticity. Through my own practice-as-research, I examine the decision-making within the preproduction of a historical drama (my short film, The Burning, 2016) in order to demonstrate the ways in which contradictory concepts of authenticity can coexist within a historical film project.
\end{abstract}

Keywords: historical film; authenticity; verisimilitude; memory

${ }^{1}$ Corresponding author. Email: dlees2@ucreative.ac.uk 
Authenticity has been a matter of debate in contributions to the Journal of Media Practice, in two instances relating to film and history. In 2015, Aaltonen and Kortii discussed the changes in the relationship between history and documentary film, highlighting the growing acceptance of re-enactment as an expressive tool, with resultant challenges to assumptions about historical authenticity (2015, 16:2). It was also a major concern for Bell and McGarry, in another filmmaker-historian collaboration, who gave an account of dilemmas and decisions in the making of a film based on a character from Irish history (2013, 14:1). Both articles discussed issues around the representation of historical figures: Desmond Bell had dramatized a life (The Enigma of Frank Ryan, 2012), whereas Jouko Aaltonen gave a documentary account of a life in his film, A Man from the Congo River (2010), using diaries and other archival sources, as well as animation and re-enactment. However, each filmmaker negotiates similar concerns associated with the representation of characters from history and reflects on their responsibilities in relation to principles of historical authenticity.

Discussions of authenticity are by no means limited to the area of media representations. As a concept it has significance across multiple areas of study, as noted by Knudsen and Waade:

the discussion of what authenticity really means has been going on in many different academic fields, from questions about realism, representation and reality in aesthetics and media studies, to 'authenticity as idea' related to national identity and cultural heritage, as well as ‘authenticity as strategy' in marketing and place branding. (2010: xv)

In this article, my intention is to develop the discourse around authenticity in film, beyond the areas of documentary and historical dramatization already discussed in this journal. My own area of practice is as a director of fiction film, with a recent interest in the representation of history on screen, so here I will develop debates around the authentic in relation to the making of historical drama. In extending the discussion to fiction film, I must emphasise that my concerns around authenticity are here limited to those of historical representation: within the writing and directing of fiction film, the term 'authentic' is also used in relation to character, emotion and 
storytelling, but these are issues outside the scope of this particular paper. In this article, I will begin by seeking an understanding of authenticity within a group of related concepts that are significant to the film practitioner: accuracy, fidelity, verisimilitude and authentication. In the final section, I will use practice-based research methodology to illuminate how a filmmaker negotiates the conflicting concerns around these concepts. Using an account of my latest work of narrative fiction, a Short Film set in the sixteenth century (The Burning, 2016), I will look at how a filmmaker finds a path through contradictory impulses in order to build an 'authentic' vision of history on screen.

Popular understanding of authenticity in historical film centres on the notion of a truthful representation of historical reality, and rests on a value-system that emphasises fidelity to the past. Some early filmmakers saw the pursuit of accuracy in the recreation of the past as a means for the spectator to re-enter their history. David Williams observes:

D. W. Griffith, director of The Birth of a Nation, was offering something extraordinary to future audiences: 'Instead of consulting all the authorities ... and ending bewildered ... you will actually see what happened. There will be no opinions expressed. You will merely be present at the making of history'. (1990:3)

Griffith’s hubristic confidence in his own depictions already begs questions around authenticity, but a serious commitment to the accurate depiction of the past is broadly evident in the work of many directors of historical film. This has been expressed through the use of form, some fictions presenting history with the devices of documentary realism, such as in the D-Day landings sequence in Saving Private Ryan (Steven Spielberg, 1998). Filmmakers working on twentieth century subjects are aware of how news images may help reinforce the authenticity of their films' depictions. The breakthrough film of Paul Greengrass was Bloody Sunday (2002), a portrait of the Bogside Massacre of $30^{\text {th }}$ January 1972, when British troops of the Parachute Regiment shot twenty-six civil rights protesters in Northern Ireland, fourteen fatally. Greengrass was certainly aware of the strength of documentary images from this event, in particular the photographs by Magnum photographer 
Gilles Peress, whose vivid image of Barney McGuigan's corpse lying on the street in a pool of his own blood became part of the cultural memory of the massacre. Greengrass adopts a careful strategy of integrating his film with these images. Marcia Blaney writes insightfully about his intentions:

Through a film style that self-consciously mimics the look of found footage and reportage style of filming, Bloody Sunday presents itself as a counterfeit historical document (2007: 127).

This is an extreme example of what analysts, including Richard Burt, have called the 'fidelity model', an approach to cinematic authenticity that strives to deliver an image of history that is completely accurate in terms of historical research. Yet we know that historical film can never achieve a 'true' depiction of the past: it is ridiculous to suppose that filmmakers can craft a documentary-real image of any period in history. Yet practitioners frequently pursue this ideal, sometimes with a level of obsession. Carnes describes one such incident in a Hollywood production based on relatively recent events in political history: the unmasking of President Richard Nixon's corruption in the Watergate scandal by the journalists Woodward and Bernstein.

In All the President's Men (1976), director Alan Pakula built an exact replica of The Washington Post newsroom in Burbank studio, going so far as to ship authentic Washington Post newsroom garbage to fill wastebaskets on the set. (2004: 47)

It is remarkable that Pakula was prepared to deploy large resources, in this case shipping refuse across a continent, to the provision of design detail that the film's audience would never see on screen. Perhaps he was striving to convince himself and his cast of the production's fidelity to the recreation of the office where Woodward and Bernstein had worked. In doing so, he was betraying an anxiety around authenticity far beyond the requirements of image making for his film.

The 'fidelity model' is strongly evident in filmmakers working today. In 2015, first-time feature director Robert Eggers produced his seventeenth-century supernatural thriller, The Witch, set amongst extreme Puritans in New England. Chris 
O'Fault reported on the elaborate efforts made by Eggers and his art department to create an accurate reconstruction of a rural community of that period:

For Eggers, paying close attention to detail was vital to capturing this reality. A former production designer himself, the writer-director tasked his "Witch" designer Craig Lathrop with building the family’s home and furniture using the same techniques and tools that would have been used in the 17th century (2016)

In The Witch, the spectator sees a small homestead made up of tiny thatched buildings set in a clearing in deep woodland. It looks indeed very 'authentic', but we can never be aware of the wooden pegs that the construction crew have used, instead of modern metal screws. Such fidelity to historical technique is similar to the obsessive detail of Alan Pakula’s production. However, while these filmmakers’ overwrought pursuit of 'authenticity' may be invisible on screen, their efforts play a very important role in building the relationship between the filmmaker and the spectator. The film crew's attention to historical detail is always used in publicity surrounding the production, with the intention of establishing the film's credibility in terms of period authenticity. Chris O’Fault was by no means the first journalist to write about a director's attention to historical accuracy ('How Robert Eggers Used Real Historical Accounts'). The long tradition of building a historical film's reputation through publicising its intensive research is also discussed in George Custen's work on biographical film:

Biopics were often sold to the public as accessible versions of history...Extravagant research efforts became, for the biopic, a way of reassuring consumers that every effort had been expended to bring them true history in the guise of spectacle (1992: 69)

The fidelity model must be seen as part of an important strategy employed by filmmakers when creating historical film: the ‘authentication' of the film in the minds of the audience. This term describes a relationship of trust, in which the filmmaker persuades the spectator to accept the historic validity of the entire world depicted. The tool used by the director to gain such trust is highly-researched (and well publicised) historical detail, and a film's Art Department is central to the cause of 
persuasion. Sarah Street describes how the accurate detail of costumes in historical film can be a part of the 'authenticating processes' of creating the cinematic world (2001: 30). It is not an easy process: filmmakers know that an alert spectator will always spot inauthentic detail in a historical film (in fact, certain viewers will delight in identifying anachronisms). However, Jonathan Stubbs describes how the buildingup of accurate detail in the frame can overcome the impulses of the most demanding spectators:

The effect of historical representation is achieved not through the repetition of any particular detail...but rather through the accretion and display of many details which collectively provide evidence not only of 'being in' the past, but also a sense of realism which potentially overwhelms and negates areas of dispute. (2013: 41)

The ambitions of historical filmmakers to generate highly-researched detail have sometimes been extreme:

In Gone With the Wind (1939), costume designer Walter Plunkett scoured museums for swatches of Civil War era gowns and fitted out a textile mill to reproduce the fabrics; the women's costumes alone cost \$100,000 (Carnes 2004: 47)

Such accounts of the production of Gone With the Wind were used prominently in the promotion of the film, with the idea of an art department 'scouring museums' lending academic weight to the authenticity of the film. It is hardly surprising that Historical Film has usually been associated with very high production budgets. This persistent feature of the form is in great part to do with issues of cinematic spectacle, but the needs of authentication have also driven the pursuit of lavish and historically accurate production design.

The adoption by filmmakers of the 'fidelity' approach to authenticity remains widespread today, as it has throughout more than a century of historical filmmaking since George Melies’ Jeanne D’Arc (1900). But there are dangers involved in the 
approach. Firstly, as historian Robert Rosenstone has commented, the most brilliantly researched historical films can be the most dull:

Films that have been truest to the facts...have tended to be visually and dramatically inert, better as aids to sleep than to the acquisition of historical consciousness. (1998: 7)

Second, the fidelity model is conceptually highly problematic. If the process of authentication is one of persuasion, based on impressive but necessarily incomplete historical detail, the filmmaker is engaging the audience in a game of speculation. The spectator is asked to accept that the historical world portrayed before them is probably - but not certainly - authentic. The basis for the term 'authentic' thus strays from the fidelity model's ideal of a verifiable, documentary-like historical reality. It is closer, in fact, to the concept of verisimilitude as discussed by Tzvetan Todorov. Although this term is popularly understood to mean a semblance of reality, a very useful definition is provided by Steve Neale in his writing on film genre: 'Verisimilitude means 'probable' or 'likely'. It entails notions of propriety, of what is appropriate and therefore probable' (1990: 46). The definition is particularly useful here because it extends the filmmaker's struggle to achieve a convincing authenticity beyond accurately-researched historical detail. The spectator will accept a cinematic portrayal of history as probably true if its depiction reflects common assumptions about the period. Popular belief becomes a basis for what is considered authentic. Anneli Lehtisalo expands on the definition and applicability of verisimilitude in discussing film:

Social and cultural verisimilitude is connected to public opinion, in that it is achieved wherever people believe a text to be true. Todorov stressed that this does not mean that social and cultural verisimilitude is the same as being true or real, but that it corresponds to discourses considered to be true...genres based on cultural verisimilitude are war films and historical dramas which utilise authentic locations, contemporary costumes and well-known historical stories. (2011: 101) 
So the nature of film's representation of historical period is based on visual elements that constitute, for the spectator, a verisimilitude of historical reality. The details presented by the filmmakers are assumed to be, with strong probability, true to a period of history. Here is an overlap with Stubbs' idea of the 'accretion and display of many details' to create an authentic historical representation, but Todorov and Lehtisalo add that these details must conform to culturally recognised assumptions about the past. The details presented in the visual style of a film, most importantly, are reoccurring features of the representation of a specific period of history, so are familiar to the spectator.

The strength of building an understanding of authenticity on this basis, constructed in the same manner as verisimilitude, comes from the recognition that an audience's acceptance of a historical representation is based as much on belief as on evidence. The filmmaker is playing with the spectator's cultural understanding of the past; to transgress too far would be to render a historical film 'inauthentic'. The tools available to the filmmaker are what Sarah Salih calls 'authenticity effects'. These are

those conventions of representing the past which, though arbitrary, are established signifiers of period. As Jonathan Rosenblum says: 'It doesn't matter if the historical details of the film are authentic. They just have to look authentic to the audience' (2009: 21)

Rosenblum is using here a definition of authentic in the sense of evidence-based fact, but challenges the assumptions behind the 'fidelity model'. For the filmmaker to persuade the spectator of their film's authenticity, a sequence of 'authenticity effects' needs to be displayed: sandals and togas for the Roman era, Tudor ruffs and halftimbered houses for Elizabethan drama, mini-skirts and Mini cars for England in the 1960s. There is a clear overlap with the analysis of signifiers in genre studies, and the idea of 'authenticity effects' is also developed in other areas of study. One very interesting example, which is useful to our consideration of the construction of authenticity in historical film, is the work of scholars in Tourism Studies, who consider authenticity in relation to 'heritage tourism'. Deepak Chhabra writes of the phenomenon of visitors' reception of a historical attraction: 
Satisfaction with a heritage event depends not on its authenticity in the literal sense of whether or not it is an accurate re-creation of some past condition, but rather on its perceived authenticity (consistency with nostalgia for some real or imagined past). Heritage is thus created and re-created from surviving memories, artifacts, and sites of the past to serve contemporary demand (2003: 705)

Having understood authenticity as a construction, it is important for the filmmaker to consider exactly how this process may operate in the spectator's mind. Robert Bourgoyne discusses historical film and how the experience of viewing it involves 'the act of imaginative recreation that allows the spectator to imagine that they are 'witnessing again' the events of the past' (2008: 7). Scholars within Memory Studies have reinforced this concept, analysing how the experience of watching film interrelates with the human memory. Alison Landsberg's work investigates the phenomenon that cinema could actually embed in spectators' personal memory scenes that 'they didn't actually live, but to which they subsequently have a kind of experiential relationship’ (1996:23). This phenomenon is of course only possible if the spectator has accepted the authenticity of the historical world depicted. Landsberg described this as a process of creating 'prosthetic memory' - 'memories which do not come from a person's lived experience in any strict sense. These are implanted memories’ (1995: 175). Yet, despite being what we might call 'non-organic' memories, they are potent, and form a vivid part of an individual's understanding of the world around them. Landsberg's understanding is similar to Bourgoyne's: the spectator imagines that they are seeing a repetition of past events, providing them with a sense of having actually been a witness of history. Their proposition actually provides some justification to D.W.Griffith's claim that his audience would 'be present at the making of history'.

What Landsberg described is the end of a continuous process in the spectator's mind. We can usefully summarise it in the following four-stage sequence: the spectator brings to the viewing of historical film their preconceived notions of a historical period 
- $\quad$ these preconceptions are then reinforced by the filmmaker, who presents both historically accurate detail and 'authenticity effects' relating to the audience's cultural knowledge of history

- $\quad$ these strategies successfully authenticate the historical fiction, enabling the spectator to accept the fictitious world

- $\quad$ the visual fiction becomes a form of imagined experience of history that occurs for the spectator while viewing a historical film.

If we look at the creative practices of historical film production, we see conscious strategies that reflect an understanding of this process. Prominent contemporary filmmakers have created images that deliberately mimic 'prosthetic' memories. While working on his first film for Steven Spielberg, Schindler's List (1993), Director of Photography Janusz Kaminski always carried an album of the photos of Roman Vishniac, whose work documented the Jewish community in Poland during the 1930s. Although his name is seldom quoted, Vishniac's celebrated black-and-white still photographs are engrained in most Western filmgoers' cultural memory of the period. Kaminski's use of black-and-white cinematography and the stylization of the film's images to reflect Vishniac's work were a powerful strategy to provide the spectator with a sense of 'witnessing again' the events of the Holocaust.

Another example of this strategy in a twentieth-century historical film is the 1976-set feature, Rush (Ron Howard, 2013). When I spoke to cinematographer Anthony Dod Mantle on the set of the Formula 1 drama, he described his struggle to create film images that exactly matched the film quality of the 1970s, to enable the audience to feel part of the historical events. Although he chose to shoot using the Arri Alexa digital film camera, Dod Mantle had painstakingly searched Europe for lenses used by film crews four decades earlier: he was delighted to show Baltars and Cooke S2s that had been used to shoot major motion pictures during the same period as Rush. This strategy ensured that the film’s images would have a familiar 1970squality that would be recognisable to his audience - an 'authenticity effect'. He also paid particular attention to the colours of the 1970s film stocks, later describing his rationale of how contemporary digital grading could further the cause of authenticity: 
I wanted to identify colors to push... with the yellows and cyans of the reversal [film stock] of that time...I started showing Ron pictures of reversal processes and Cibachromes (Hope-Jones, 2013)

As with Janusz Kaminski during the making of Schindler's List, this strategy was one in which the new film images reflect the quality of the photographic archive of the historical period. Dod Mantle and Kaminski show an instinctive awareness of the processes of 'prosthetic memory', in which the filmed or photographed images of history are confused in the collective memory with the events themselves. The Directors of Photography knew that audiences would be highly likely to accept their films' authenticity if the cinematography was related to popularly recognisable images of the historic period.

Such strategies by filmmakers show a conscious understanding of the conception of authenticity as a construction. The question, then, is why contemporary film directors, such as Robert Eggers, still hanker for the 'fidelity model', in which their representations of history strive towards a researched, 'true' image of the past. The answer may be in the essential qualities of the medium. Filmmakers, by using a camera, are necessarily entangled in issues around reality. The notion of 'indexicality' is invoked by the act of staging action before a camera: the spectator expects that what is projected on the screen is a real depiction of events that occurred on set in real time. This creates a friction with the spectator's simultaneous awareness that it is a fiction unfolding before them; it is the conundrum of fiction film that was described by Robert Bresson, who described cinema as 'Not absolutely realistic, because it is theatrical and conventional. Not absolutely theatrical and conventional because it is realistic' (1986: 63).

I think it possible to argue that the practice of historical filmmaking, as well as the watching of these films, can simultaneously rest on conflicting ideas of authenticity. The anxiety of filmmakers struggling to create a believable cinematic world can lead to contradictory decision-making, and within a single film we can observe different strategies at work. Through my practice-as-research, I hope to clarify how contradictory approaches can be adopted by the same filmmaker during the same film project. 
Key assumptions underlie the decision-making that I was involved with in the preparation of The Burning. Like all filmmakers embarking on a historical film project, I needed to negotiate a relationship with my intended spectators' assumptions about the historical period. In planning my film, I was aware of the images, artifacts, even the sounds of the past that may be present in the audience's understanding of Tudor England. This will be based primarily on a previous diet of historical film and television drama. So a factor governing decision-making from the beginning of preproduction was an awareness that I cannot create a cinematic environment that is entirely unfamiliar to the audience: to effectively engage the spectator, my film's images must contain 'authenticity effects' relevant to the period. As Sue Harper writes in her study of the Gainsborough Film Studio, famous for its historical filmmaking in the 1940s,

The art director of 'costume' melodrama has to indicate a past which is both familiar and stimulating; the audience of a successful film must recognise familiar signs and confidently fill in the 'gaps' in the discourse (1987:108)

My audience will be looking for similarities with the production design of other films set in sixteenth-century England: any significant dissimilarities may disrupt their acceptance of the cinematic world being created.

However, a second factor guiding preproduction decision-making conflicted with this understanding of constructed authenticity. The Burning, set on the day in 1558 when the Catholic Queen of England, Mary Tudor, died, was intended to dramatise the turbulence of the Reformation not as it is normally shown, in the Tudor court, but as it was experienced in ordinary rural communities. The film looks at the religious conflict in England without offering the spectator the familiar pleasures of glamour (The Tudors, TV series, 2007-10) or star attraction (Elizabeth, Shekar Kapur, 1998). The ambition of my film project was to portray the conflict in a manner that the audience can believe is a more honest representation of sixteenth century England than they have seen elsewhere. I wanted The Burning to be a 
highly-researched and accurate image of rural society four-hundred-and-sixty years ago: a principled attachment to the 'fidelity model' of authenticity.

The tension emerged very early in preproduction. Even during screenwriting, I was faced with a dilemma: to write dialogue in the English that was spoken in the sixteenth century would sound nonsensical to today's film audience. The cinema audience expects a language that sounds different from modern English, but is easily comprehensible - what we might describe as 'post-Shakespearean'. To communicate effectively with the audience, I must write dialogue in a voice which I know to be historically inaccurate. During rehearsals with my leading actors, George Watkins and Elizabeth Morton, I discussed my anxiety. Their insight was particularly interesting: coming to the script as a text, they had discovered an emotional honesty in the dialogue that supported their task of creating truthful characters, overriding any questions of its inaccuracy.

Early preproduction decisions on film locations involved frequent considerations around authenticity. At the 'Weald and Downland Open Air Museum' near Chichester, Sussex, I found a very suitable location for the film: Bayleaf Farmstead is a fifteenth century building which was dismantled in 1972 and brought to the museum for reconstruction. Today, it is presented as it would have looked in the 1540s - just ten years before the death of Mary Tudor and the action of The Burning. The accuracy of the location's period, with the detail provided by the museum, was a major opportunity for the film and conformed to my intention to accurately represent the historical world. The half-timbered look of the farmhouse also matched familiar images of Tudor England - it would be an 'authenticity effect' with useful impact on the spectator. 


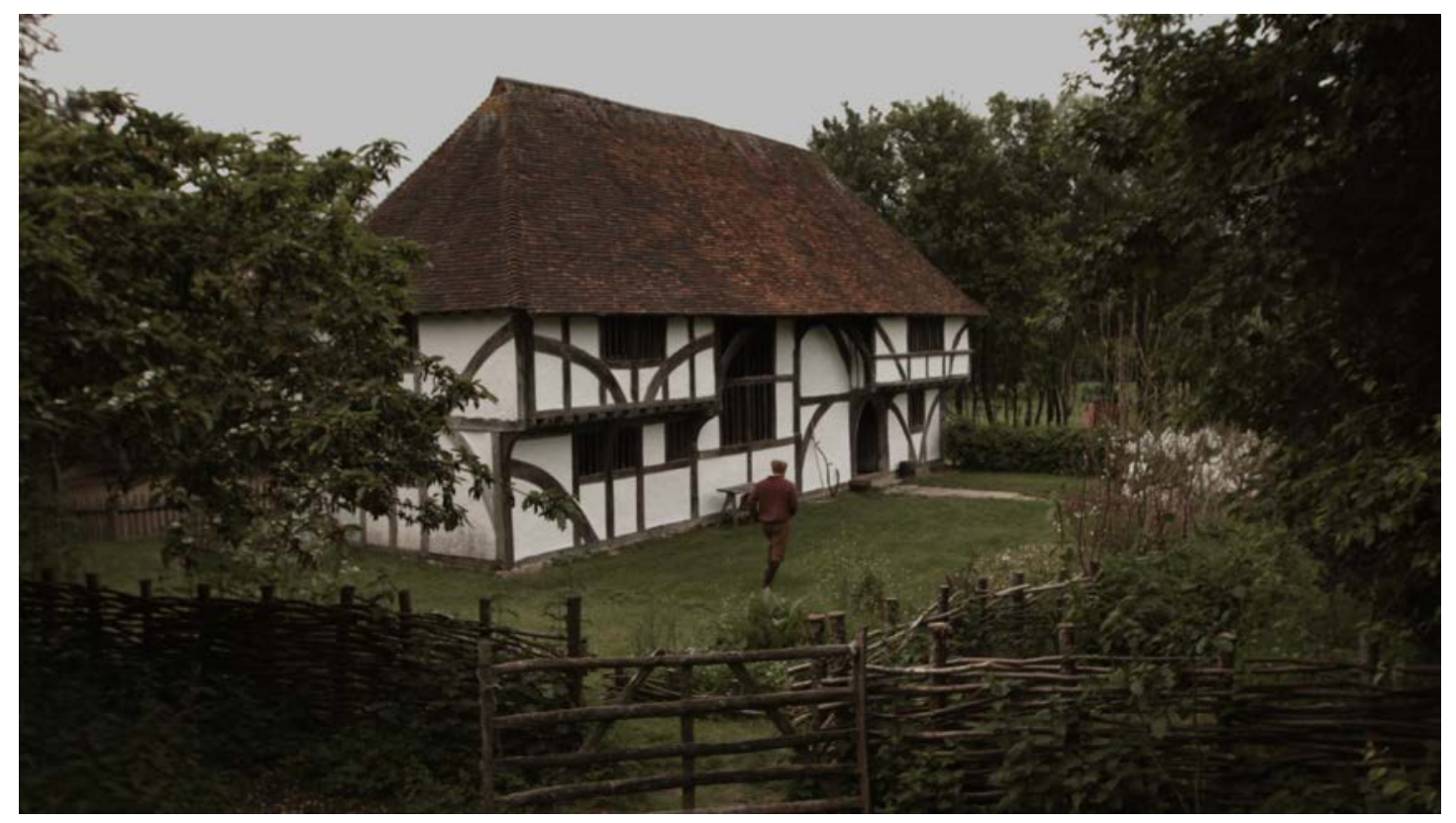

Figure 1: Still photo from The Burning: Bayleaf Farmhouse, location at the Weald and Downland Open Air Museum, West Sussex.

However, it was the costume decisions that generated the most complicated discussions about authenticity. In this aspect of design, I was determined to create a film that portrayed ordinary people in Tudor England with accuracy. In part, this was to distance the film from the glamourised portrayals of the Tudors seen in recent UK television drama and feature films. My research showed, for instance, that in Tudor England, it was inconceivable not to wear a hat. This cultural habit was also enshrined in law: the 'Sumptuary Laws' decreed that anyone seen without a hat - the famous ‘Statute Cap' for males - would face a heavy fine. Historical evidence shows examples of men being fined several pounds, which was a heavy punishment at a time when the average wage was little more than two pounds per year. Yet in the traditions of Historical Film set in the period, representations frequently show bareheaded Tudors. In a sequence in Shekhar Kapur's Elizabeth: the Golden Age (2007), Cate Blanchett appears as the queen, bareheaded with long, flowing red hair. It is historic nonsense: the Tudors considered hair to be exceptionally erotic; women, like men, suffered strict restrictions in relation to head-covering. Kapur's Elizabeth would have sexually aroused and enraged her subjects. I made an early decision to depart from the cinematic conventions with such inaccurate representations of Tudor headwear. To ensure historical accuracy, I organised a workshop for my costume department and invited one of the country's leading experts on Tudor clothing, Dr. Cathy Flower-Bond, as a consultant. We made precisely 'authentic' Tudor hats - the 
famous 'Statute Cap': round, floppy and made of wool cloth. However, despite being confident in the historic accuracy of these hats, as a filmmaker I was presented with a problem: if I were to show all my male characters in these caps, as the Sumptuary Laws decreed, they would appear like a parade of academics at a degree ceremony. My film's protagonist is a desperately serious man, consumed by grief and rage: I could not imagine the audience engaging with his story if there were a link in their minds between this ordinary farmer and a contemporary university professor. I knew that the film's audience would not be aware of the restrictions of the Sumptuary Laws: their assumptions about the Tudor period would be based on other film and television representations, which have imprinted inaccurate conceptions of the time. So I compromised my goal of presenting an accurate image of ordinary people in Tudor England: my protagonist wears a simple wool beanie.

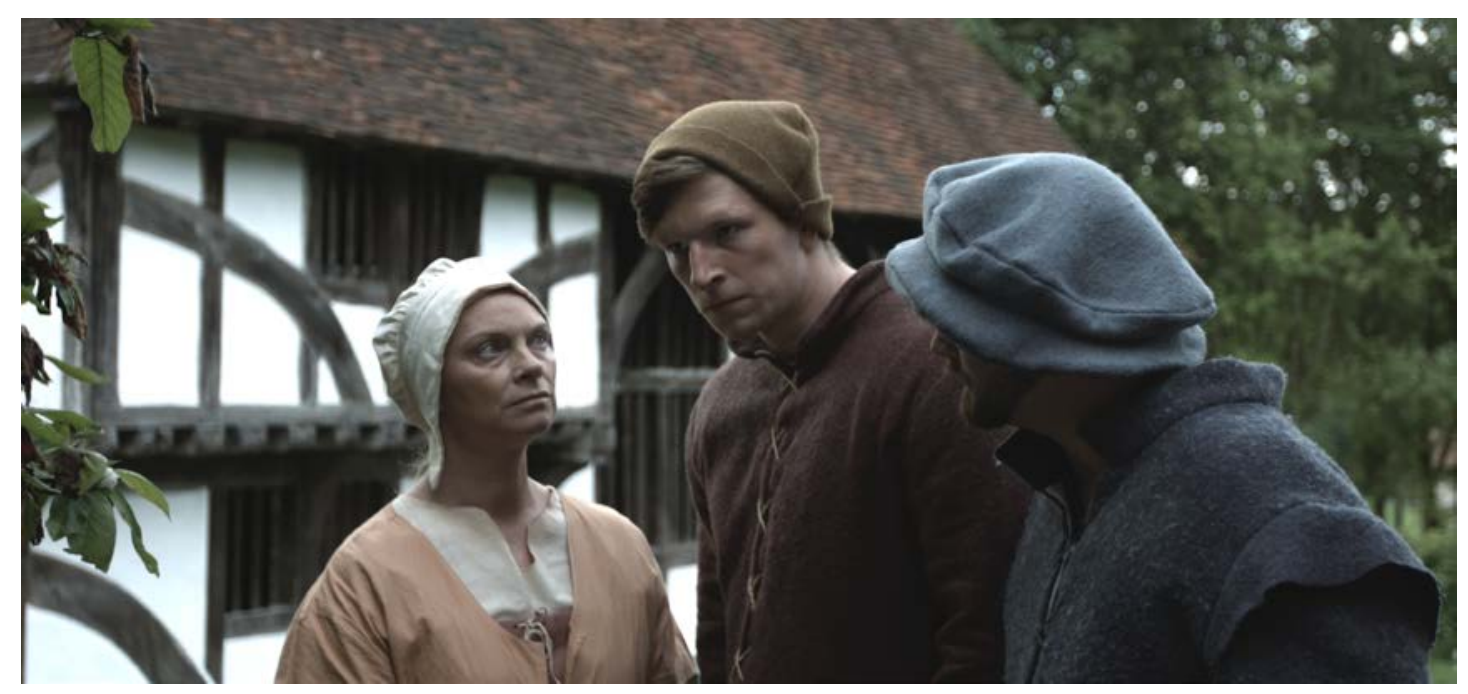

Figure 2: George Watkins as 'Richard' in The Burning

Issues of character and drama were distancing my creative decisions from the 'fidelity model' ideal of a historically-accurate image of Tudor villagers. This was reinforced when making decisions about the costume of the film's second character, a church Altarboy. The Burning is about an explosion of intolerance after the death of the Catholic queen Mary, and the victim of this outburst is the eleven-year-old assistant to the village Priest. Central to the drama is the sense of the Altarboy's innocence, and his otherness in relation to the villagers. A Tudor Altarboy would have worn a simple, floppy version of the 'Statute Cap’. However, I had cast a young actor with an impressive head of curly hair, which emphasises his look of 
innocence. I had no desire to cover this hair, which makes a useful connection to the images of angels in sixteenth century paintings. To emphasise the Altarboy's otherness, I again broke from historical accuracy, choosing to have him as the only character in the film without any headcovering. Recalling my earlier criticism of Shekar Kapur's bareheaded Elizabeth, what is interesting is how the filmmaker's primary visual concern is the creation of strong characters to serve the narrative, a priority that overrides considerations of historical accuracy.

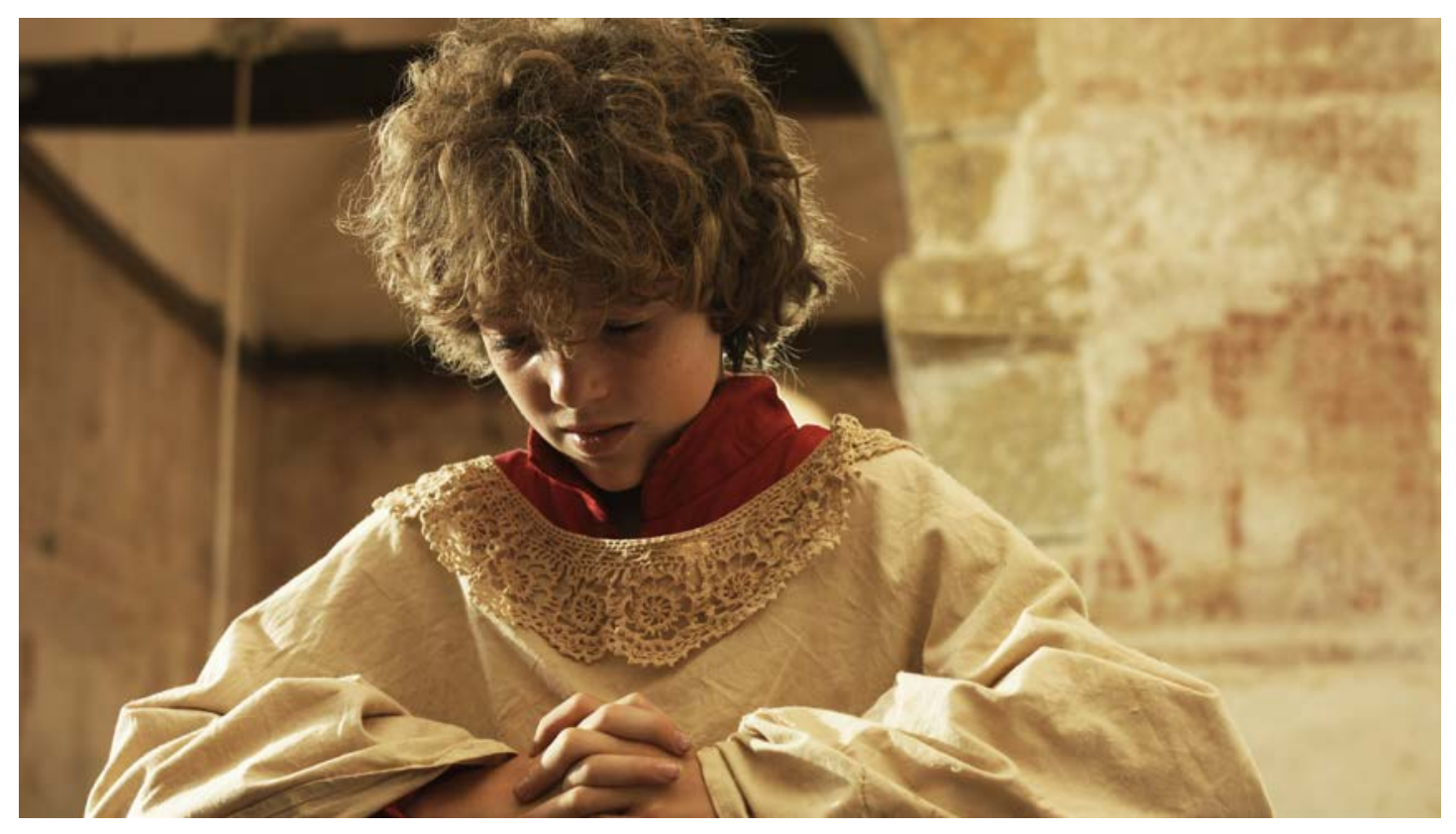

Figure 3: Theo Lees as the bareheaded Altarboy

My practice-as-research was already demonstrating to me the fragility of the 'fidelity model' of authenticity when faced with the creative considerations of filmmaking. However, further decisions on costume showed how an attempt to engage with the notion of authenticity as a construction, by conforming with what Salih described as the 'conventions of representing the past', might also be vulnerable in the heat of preproduction. In The Burning, the central authority figure is a Protestant lay-preacher, Thomas, who leads the community's campaign for revenge after the violent repressions of Mary Tudor's reign. The familiar image that I wanted to engage with was that of the Puritan in sombre black clothes and white collar. I was aware that this would be historically inaccurate: later in the seventeenth century, it would become a hallmark of the Puritans, who were mostly drawn from the richer merchant classes, but in 1558 such costume would not have appeared in a small 
village. However, my character, Thomas, would be linked by the film's audience with preconceived images of intransigent Puritans, and this would be an 'authenticity effect' that would contribute to the authentication of the historical world portrayed in The Burning.

During preproduction, I volunteered to dye the wool cloth for Thomas's costume: taking several metres of our pale cream cloth and quantities of Dylon's black fabric dye, I followed the procedure of dyeing, which involved several hours of churning the wool to make it absorb the colour. However, the result when finished was a pale blue. I repeated the work with a fresh batch of black dye, but after many hours of churning, rinsing and drying, the wool cloth was no more than a darker shade of blue. I repeated it again, only to achieve a rich midnight blue, which was still far from my intended black. At this point, I discussed the problem with our Historical Advisor, Cathy Flower-Bond. She explained to me that my painstaking work in trying to dye cloth black was exactly the experience of sixteenth century textile artisans. There was no black dye available in that period: to achieve the colour, Tudor workers would use indigo blue and repeat the dyeing process with this colour nine times. Just as in my experience, the colour of the cloth would darken with each dyeing. The labour involved was the reason why black cloth was so expensive and become a symbol of privilege and status in Tudor society. Now I was able to look at my own midnight-blue wool cloth not as a failure of my work in helping the Costume department, but as a possible contribution to the film's historical accuracy. Thomas could be a wealthy man of the village who aspires to wear the black clothing of a higher class, but can still only afford a cheaper colour. The midnight blue represents his aspiration; we can imagine that the next generations of his family will wear the black-and-white of the Puritans, although he has not yet reached this status. The struggle with wool dyeing had unexpectedly generated a vivid understanding of Thomas's character. However, to accept this blue costume would be to abandon the 'authenticity effect' of a Puritan dressed in black. I was faced with a dilemma: would my audience require the instantly-recognisable image of Tudor Protestantism in order to understand the character of Thomas? I took the decision to abandon the archetype and embrace the historically-accurate blue. 
A particular benefit of practice-as-research is its ability to help us understand how chance, and unexpected influences, impact on the creative process. During the making of The Burning, I encountered a second instance of how the film's achievement of authenticity was aided thanks to the intervention of an unexpected source. For the role of Judith, the poor servant of the household in The Burning, I cast Jorjana Ingham, an actor who brought an intense energy to her preparation for the role, and an enthusiasm for the historical research required in developing her character. Ingham's professional training is in the 'Method' - an approach to preparing a character that has much overlap with debates around authenticity - and she sought any means possible to understand the social and cultural background of Judith. She joined the Costume-Making Workshop led by Dr.Cathy Flower-Bond; having developed the knowledge and sewing skills required, Ingham begged me that she should make her own costume. Authenticity, in the sense of historical accuracy, was part of her rationale: a poor widow such as Judith would have made all her own clothes in the sixteenth century. This was a request that a sensitive Director could not refuse: my working relationship with actors is to encourage them in whichever approach they choose to create depth in their character. If Ingham believed that sewing her costume would help prepare her performance, I was reluctant to deny her the opportunity. Initially, this seemed to me to be a relatively safe decision, however I was not prepared for the result of her limited skills as a seamstress. Judith’s costume looks quite different from the other characters' in the film: it is misshapen, unevenly stitched, lopsided and too big.

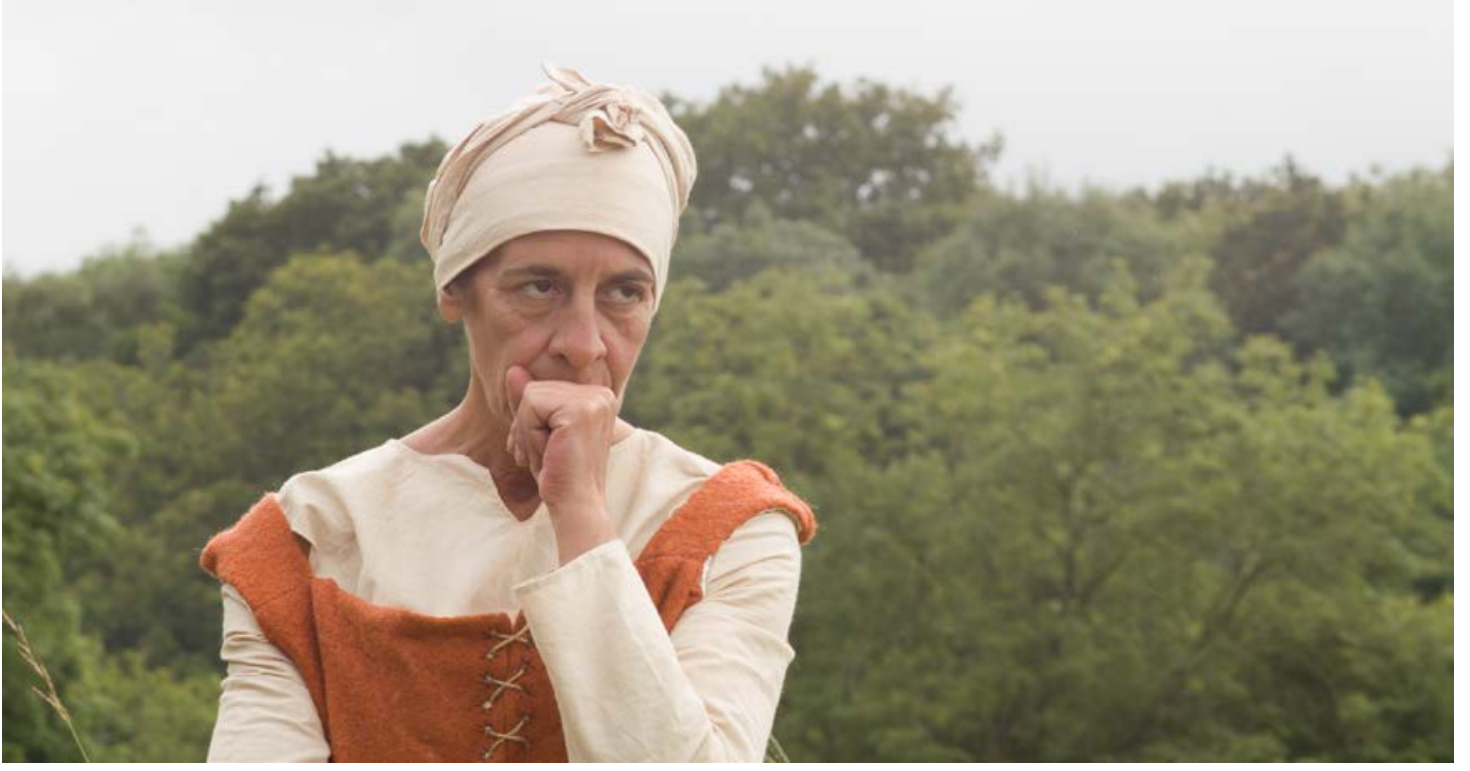

Figure 4: Jorjana Ingham as ‘Judith’ 
But while my Costume Designers were dismayed by the quality of Ingham's work, for me this costume was perfect: its rough and amateurish quality emphasises the poverty of the old woman; Ingham's body looks shrunken within the oversized 'kyrtle', as if she is living a life of hunger. Ingham's intervention brought unexpected visual meaning to her character's costume and offered a new insight into the overall costume design. Prior to her request to make her costume, I had not discussed with the Designers the idea of varying the actual quality of craft in the making of our different characters' clothing. Costume professionals could only conceive of making the actors' costume to the best of their ability. It was Ingham's participation in the The Burning's costume-making that unexpectedly added a new layer of meaning within the film's mise-en-scène: some costumes were well-made, others very poorly cut and stitched. Most importantly, the actor's intervention impacted unexpectedly on my struggle for a 'fidelity model' of authenticity in the film's costume design. Ingham supplied an enhanced accuracy to our costumes, the homemade quality of clothes that would have been common in a sixteenth century English village.

\section{CONCLUSION}

The practice of making historical film is replete with conflicting approaches to authenticity. Despite the theoretical clarity in the debate on authenticity, we must understand that contradictions exist within the minds of filmmakers during production. Even when a filmmaker is aware of the complex issues of constructed authenticity, there will frequently be a personal commitment to accuracy, to the 'fidelity model' of representing the past. Williams suggests that this contradiction also exists for writers and theorists of film: despite our understanding of the constructed nature of authenticity, none of us can completely free ourselves from an attachment to the fidelity model: 'the demand for authenticity, for the real thing, works subtly in the minds of all watchers of film' (1990: 3). For filmmakers during the creative process, the vain pursuit of 'the real thing' is not incompatible with a sophisticated handling of 'authenticity effects', which, although historically inaccurate, engage the spectator in the authentication of the film. The tensions witnessed here are perhaps derived from the very nature of engaging in history. The historian Robert Rosenstone makes a comparison between the academic writing of history and the making of historical film: he finds that they are 
similar in at least two ways: they refer to actual events, moments, and movements from the past, and at the same time they partake of the unreal and the fictional, since both are made out of sets of conventions we have developed for talking about where we human beings have come from (2006: 2)

Rosenstone's observation of the contradictions at the heart of all approaches to history underscores the enduring dilemma for filmmakers struggling with authenticity. The practice of historical film will remain an anxious balance between the thirst for accuracy and an adherence to the many conventions and constructions which film uses in its engagement with history.

This article was developed from a paper delivered at the Journeys Across Media conference (JAM) at the University of Reading in 2014, where the author is conducting research towards a PhD exploring 'Modes of Creative Production' in fiction film directing.

\section{References}

Aaltonen, J \& Kortti, J (2015) 'From evidence to re-enactment: history, television and documentary film', Journal of Media Practice, 16:2, 108-125

Bell, D \& McGarry, F (2013) 'One cut too many? History and film: A practice-based case study’, Journal of Media Practice, 14:1, 5-23

Blaney, A, 'Remembering Historical Trauma in Paul Greengrass's Bloody Sunday' in History and Memory, Vol. 19, No. 2 (Fall/Winter 2007), pp. 113-138 Published by: Indiana University Press Stable URL: http://www.jstor.org/stable/10.2979/HIS.2007.19.2.113

[Accessed: 15/03/2014 07:43]

Bresson, R (1986) Notes on the Cinematographer, London: Quartet

Burgoyne, R (2003) 'Memory, history and digital imagery in contemporary film' in Grainge, P, ed (2003) Memory and Popular Film (Manchester: Manchester University Press)

Burgoyne, R (2008) The Hollywood Historical Film (Oxford: Blackwell) 
Carnes, M.C. (2004) 'Shooting Down the Past: Historians vs. Hollywood' in Cineaste 29/2, 45-49

Chhabra, Deepak, Healy, Robert and Sills, Ering (2003) 'Staged Authenticity and Hertiage Tourism’ in Annals of Tourism Research, Vol. 30, No. 3, pp. 702-719

Custen, George F. (1992) 'Making History’, in Landy, M (ed)(2001) The Historical Film: History and Memory in Media (London: The Athlone Press)

Harper, S (1987) 'Historical Pleasures: Gainsborough Costume Melodrama', in Landy, M (ed)(2001) The Historical Film: History and Memory in Media (London: The Athlone Press)

Hope-Jones, M (2013) 'Anthony Dod Mantle, ASX, BSC, DFF buckles up on Ron Howard's fast-moving Formula 1 racing drama’ Available at http://www.theasc.com/ac_magazine/October2013/Rush/page1.php [Accessed 30.12.2015]

Knudsen, Britta Tim and Waade, Anne Marit (2010) Re-investing Authenticity: Tourism, Place and Emotions Bristol: Channel View Publications

Landsberg, A (1995) 'Prosthetic Memory: 'Total Recall' and 'Blade Runner' in Featherstone, M and Burrows, R (eds) (1995) Cyberspace, Cyberbodies Cyberpunk: Cultures of technological embodiment' (London: Sage)

Landsberg, A (1996), Prosthetic Memory: The Logic and Politics of Memory in Modern American Culture (PhD dissertation, University of Chicago)

Lehtisalo, A (2011) 'As if Alive before Us: The Pleasures of Verisimilitude in Biographical Fiction Films’ in New Readings 11 (2011): 100-17

Neale, S (1990) ‘Questions of Genre’ in Screen 31.1: 45-66

O’Falt, Chris (2016) 'How Robert Eggers Used Real Historical Accounts' in Indiewire 19.2.2016 Available at: http://www.indiewire.com/2016/02/how-roberteggers-used-real-historical-accounts-to-create-his-horror-sensation-the-witch-67882/ Accessed 21.07.2016

Purse, L (2013) Digital Imaging in Popular Cinema (Edinburgh: Edinburgh University Press)

Rosenstone, R.A. (1998) Visions of the Past: The Challenge of Film to our Idea of History (Cambridge, MA: Harvard University Press),

Rosenstone, R.A. (2006) History on Film/Film on History (Harlow: Pearson Education)

Salih, S (2009) 'Cinematic authenticity-effects and medieval art: a paradox' in Bernau, Anke and Bildhauer, Bettina (eds) Medieval Film, Manchester: Manchester University Press 
Shapiro, J (2012) 'Using Your Head' Available at http://blog.britishmuseum.org/2012/04/25/using-your-head/ [Accessed 3.11.2015]

Street, S (2001) Costume and Codes in Popular Film (Chichester: Wallflower)

Stubbs, J (2013) Historical Film: a critical introduction (London: Bloomsbury Academic)

Sturken, M (1997) Tangled Memories: The Vietnam War, the Aids Epidemic, and the Politics of Remembering (Berkeley: University of California Press)

Todorov, T (1977) Poetics of Prose (Oxford: Basil Blackwell)

Toplin, R.B. (2007) 'In Defense of the Filmmakers' in Francaviglia, R.V., Rodnitzky, J and Rollins, P.C. Lights, Camera, History: Portraying the Past in Film (Texas:

A\&M University Press)

David Williams (1990) 'Medieval Movies' in The Yearbook of English Studies, Vol. 20, $1-32$ 